\title{
The effect of sharia share selection based on financial ratio and corporate governance mechanism on the quality of company profit
}

\section{Nida Ulya Shofana, ${ }^{1}$ Faris Shalahuddin Zakiy, ${ }^{2}$ Muchammad Fauzi, ${ }^{3}$ Singgih Muheramtohadi, ${ }^{4}$ Najim Nur Fauziah ${ }^{5}$}

1,2,3,4Universitas Islam Negeri Walisongo Semarang, Indonesia 5 IIiBF, International Islamic University Malaysia, Malaysia email: deafebyseptiani19@gmail.com

\begin{abstract}
Purpose - This study aims to obtain empirical evidence regarding the effect of Islamic stock selection based on financial ratios (debt to assets ratio, debt to equity ratio, non-halal income ratio) and corporate governance mechanisms (managerial ownership, independent commissioners, institutional ownership, audit committee) on company earnings quality.
\end{abstract}

Method - The population of this research is all companies that are members of the Indonesian Sharia Stock Index in 2017-2019. The sample selection used purposive sampling method and obtained 67 sample companies. This study uses secondary data with multiple linear regression analysis method.

Result - Debt to assets ratio, managerial ownership, institutional ownership, and audit committee have no significant positive effect on earnings quality. The ratio of non-halal income has a negative and significant effect on earnings quality. Meanwhile, the debt to equity ratio and independent commissioners do not have a significant negative effect on earnings quality.

Implication - Companies that are members of the Indonesian Sharia Stock Index are expected to be able to improve the quality of their financial reports. On the other hand, investors are expected to find out and study the company's annual report as a material consideration for investment decisions.

Originality - The originality of the research is this study intends to develop previous research by examining the selection criteria for sharia shares and corporate governance mechanisms.

Keywords: financial ratios; coporate governance; earnings quality 
Nida Ulya Sofana et al.

\section{Introduction}

The Indonesian Sharia Stock Index (ISSI) is an indicator of the performance of the Islamic stock market in Indonesia in the form of all shares JIAFR | 242 listed on the Indonesia Stock Exchange (IDX) and the Sharia Securities List (DES) published by the Financial Services Authority (Otoritas Jasa Keuangan/OJK). Companies that are members of ISSI must pass two stages of selection, namely the selection of the suitability of the company's main activities with sharia principles and selection based on financial ratio analysis of the company's financial statements (Sugiarti \& Habibi, 2017). ISSI's capitalization value since its launch in May 2011 has tended to increase in line with the increasing number of companies making public offerings on the capital market as an alternative source of funding.

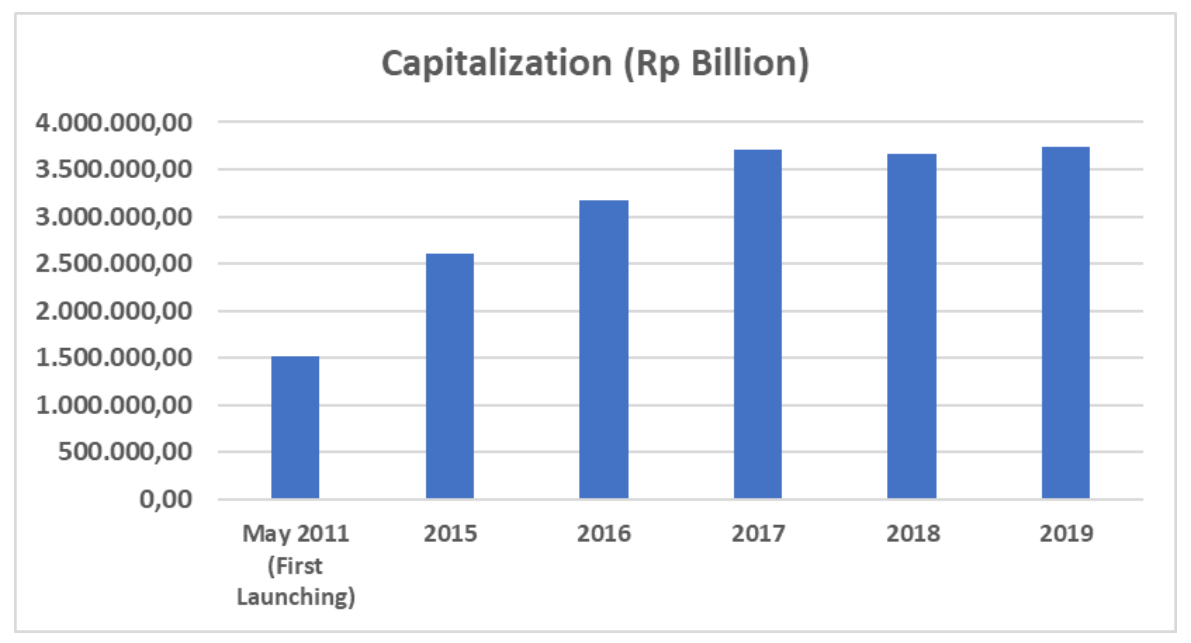

Figure 1. Capitalization of Indonesia Sharia Stock Index

Source: Processed secondary data, 2020 
The effect of sharia share selection based on financial ratio and ...

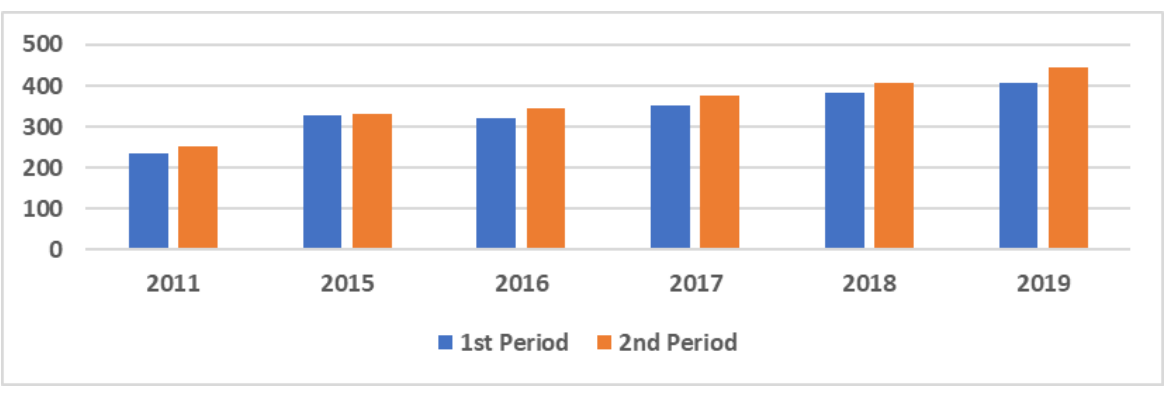

JIAFR | 243

Figure 2. Sharia Stock Growth

Source: Processed secondary data, 2020

The selection of Islamic stocks based on financial ratios is expected to improve earnings quality so that investors' assessment of Islamic stocks will be better. According to Dechow and Schrand in Laela and Habibi (2017), earnings information is an important aspect that can help investors predict future cash that will be received. Meanwhile, cash is the realization of high quality corporate earnings (Murniati et al., 2018). On the other hand, according to the research of Hakim and Rashidian (2004) and Buchdadi et al. (2012), the existence of quantitative screening on Islamic stocks has been proven to be responded positively by investors.

Corporate governance mechanisms are considered as another factor that has the opportunity to improve earnings quality because information about earnings is an indicator of measuring the company's operational performance. In addition, investors understand that the profits contained in the financial statements are the result of a series of management policies (Sugiarti \& Habibi, 2017). Therefore, investors must have the convenience of obtaining profit information, while companies are required to be able to present quality earnings in their financial statements (Murniati et al., 2018).

The position of earnings information is expressly stated in the Statement of Financial Accounting Concept (SAFC) that earnings can be used to assess management performance and predict earnings capability as well as assess investment or credit risk. Therefore, profit information becomes an evaluation material for internal parties or management, company owners, 
Nida Ulya Sofana et al.

creditors, and investors. Earnings quality can decrease if earnings are not presented in actual conditions because they have the potential to mislead users of financial statements (Tanjung, 2019).

JIAFR | 244

Transparency of financial reporting refers to the values of truth, honesty, fairness and fairness so that the information presented in it is of relevance and reliability. Relevant financial reports are able to provide consideration for business decisions to be taken because of their timliness, predictive value, and feedback value. On the other hand, the reliability of financial statements describes the condition of the company in a precise, tested, and neutral manner. This concept is explained in QS. Al Baqarah: 42 (Zulkifli \& Sulastiningsih, 1998).

There are various previous studies related to the selection of Islamic stocks based on financial ratios, corporate governance mechanisms, and earnings quality. Research by Sugiarti and Habibi (2017) prove the positive impact of the selection criteria of sharia shares based on financial ratios on earnings quality. The selection criteria in this study were measured by the ratio of interest-based debt, the ratio of receivables, and the ratio of interest income and non-halal income. It is supported by the research of Chung, Sandra, and Jeong (2004) that limiting debt ratios in companies makes it difficult for managers to manipulate earnings. Companies with high debt ratios are more motivated to fulfill debt contract agreements so that there is a negative relationship between leverage and earnings quality (Ali et al., 2007).

Research by Marsela and Maryono (2017) leads to different results from the above studies. Leverage has no positive and significant effect on earnings quality. Furthermore, research by Wati and Putra (2017) shows that leverage has no significant effect on earnings quality. More conservative debt management, inventory management, and credit sales efficiency can improve the earnings quality of companies with relatively high debt to assets ratio (Wati \& Putra, 2017). Research by Murniati, Sastri, and Rupa (2018), Nugrahani (2019), and Anjelica and Albertus (2014) show similar results, namely the debt to equity ratio has no effect on earnings quality. 
Research by Murniati, Sastri, and Rupa (2018) also prove the influence of several indicators in corporate governance. As a result, managerial ownership and independent commissioners have no effect on earnings quality (Murniati et al., 2018). According to Puspitowati and Mulya (2014), managerial ownership, institutional ownership, and the audit committee have no significant effect on the direction of a negative relationship to earnings quality, while the board of commissioners does not have a significant effect on the direction of a positive relationship with earnings quality. Meanwhile, research by Moradi and Nezami (2011) does not show a significant positive effect between institutional ownership on earnings quality.

The above research was supported by Natasha and Novia (2017) and Budianto, Yuli, and Suhendro (2018) concluded that managerial ownership has no effect on earnings quality. On the other hand, research by Novieyanti and Kurnia (2016) and Lolimpung (2020) show that institutional ownership and independent commissioners have no effect on earnings quality. Furthermore, research by Yushita, Rahmawati, and Hanung (2013) comes to the conclusion that managerial ownership, institutional ownership, and audit committee have no significant effect on earnings quality. This is similar to the results of Salleh and Haat's research (2014) that the audit committee has no effect on earnings quality.

Different research results related to corporate governance mechanisms and earnings quality are seen in the research of Oktaviani, Emrinaldi, and Vince (2015) which concludes that institutional ownership, managerial ownership, the board of commissioners, and the audit committee have a significant effect on earnings quality. This study brought similar results to the research conducted by Quynh and Thi (Nguyen et al., 2021) that managerial ownership has a positive effect on earnings quality. This result is supported by Meidhayanti and Wenny (2016), namely managerial ownership, institutional ownership, independent commissioners, and audit committees have a significant positive effect on the company's earnings quality.

Research by Novieyanti and Kurnia (2016) shows that managerial ownership is known to have an effect on earnings quality and has a positive 
Nida Ulya Sofana et al.

relationship and the audit committee has a significant effect on earnings quality. This result is supported by Polimpung (2020) which shows the results that managerial ownership and audit committee have an effect on earnings quality. In addition, Budianto, Yuli, and Suhendro (2018) state that institutional ownership affects earnings quality. Furthermore, research by Yushita, Rahmawati, and Hanung (2013) comes to the conclusion that the proportion of independent commissioners has a negative effect on earnings quality.

The results of various studies are one of the factors for this research to be carried out. The originality of the research lies in the object of research, namely the annual reports of companies incorporated in the Indonesia Sharia Stock Index for 2017-2019. Debt to assets ratio, debt to equity ratio, and nonhalal income ratio were chosen as variables referring to POJK Number 35/POJK.04/2017 and Fatwa No: 40/DSN-MUI/X/2003. Meanwhile, managerial ownership, independent commissioners, institutional ownership, and audit committee were chosen as variables because these four aspects represent the corporate governance mechanism. This study intends to develop previous research by examining the selection criteria for sharia shares and corporate governance mechanisms.

Based on the explanation above, this study aims to obtain empirical evidence regarding the effect of sharia stock selection based on financial ratios (debt to assets ratio, debt to equity ratio, non-halal income ratio) and corporate governance mechanisms (managerial ownership, independent commissioners, institutional ownership, and audit committee) on the earnings quality of companies that are members of the 2017-2019 Indonesian Sharia Stock Index.

\section{Literature Review}

\section{Selection of Sharia Stocks Based on Financial Ratios}

The selection (screening) of sharia shares is one of the government's efforts to create a capital market that adheres to sharia principles. The 
existence of sharia stock screening embodies the optimistic attitude of investors, especially Muslim investors to invest in sharia issuers (Yuwana, 2018). The sharia stock screening method generally has two criteria, namely qualitative criteria (business screening), and quantitative criteria (financial screening) (Ramdani \& Aziz, 2018). The qualitative criterion is the fulfillment of the halal aspect which is a basic principle and is absolute for every issuer or company in order to become sharia shares (Fielnanda, 2017). Quantitative criteria (financial screening) are selection criteria for sharia shares by considering financial ratios, including comparisons between total interestbased interest and total assets and comparisons between total interest income and non-halal income with total income (Muchtar, 2019).

The amount of financial ratios that is used as one of the identification criteria for sharia shares in Indonesia is regulated by the Financial Services Authority. Financial Services Authority Regulation Number 35/PJOK.04/2017 concerning Criteria and Issuance of Sharia Securities List stipulates that sharia shares must meet the following financial ratios: (1) Total interest-based debt compared to total assets of not more than $45 \%$ (forty five percents), (2) Total interest income and other non-halal income compared to total operating income and other income is not more than $10 \%$ (ten percents). Along with the POJK, DSN through its fatwa stipulates criteria that issuers or public companies that issue sharia securities may not have debts to usurious financial institutions with a more dominant portion of their capital.

\section{Agency Theory}

The relationship between corporate governance mechanisms and earnings quality can be explained through agency theory. Agency theory is defined by Jensen and Meckling (in Luayyi, 2012) as a contract between one or more people (principal) who employs another person (agent) to perform services on behalf of the principal and gives the agent the authority to make decisions. Both the principal and the agent tend to maximize benefits and positions using individual contact interpretations (Fitri et al., 2019). 
Nida Ulya Sofana et al.

The existence of separate ownership and control increases the occurrence of conflicts of interest so that the principal and agent try to maximize the contractual benefits at the expense of the other party. Managers are moved to manipulate financial statements for promotion and achieving certain contractual relationships. This action certainly affects the quality of the company's earnings (Asogwa et al., 2019). The basic assumption of agency theory refers to the actions of workers, especially top management which is based on their own will, so it is necessary to establish a mechanism to control workers (Prasetyantoko, 2008).

\section{Corporate Governance}

According to Muid (2009), Forum for Corporate Governance in Indonesia (FCGI) defines corporate governance as a set of rules to regulate the flow of relationships between shareholders, company managers, and internal or external stakeholders relating to the rights and obligations of each party. Corporate governance has five principles, namely transparency, accountability, responsibility, independence, and fairness and equality (Novieyanti \& Kurnia, 2016).

\section{Managerial Ownership}

Managerial ownership are shareholders as well as company owners who carry out the authority and duties, and actively participate in decision making so that they can influence company policies (Rivandi, 2018). Managerial ownership is measured as the number of shares owned by the manager or the management divided by the number of shares outstanding (Groot \& Knecht, 2013).

\section{Independent Commissioner}

An independent commissioner is a board of commissioners who is able to act independently due to the absence of financial relationships, share ownership, or family relationships with other members of the board of commissioners, directors, shareholders and other relationships. The 
proportion of independent commissioners is determined by at least $30 \%$ of all members of the board of commissioners (Sugianto \& Sjarief, 2018). The existence of independent commissioners is expected to be able to minimize problems that could potentially arise between the board of directors and shareholders (Pratama \& Sunarto, 2018).

JIAFR | 249

\section{Institutional Ownership}

The existence of an institution or institution as the owner of some shares in the company is considered more effective in carrying out the supervisory function seen from the nature of institutional investors who are concerned with the company's performance in the long term (Nadirsyah \& Muharram, 2016). Institutional investors are experienced investors (sophisticated investors) as well as investors who have good company records (informed investors) (Indrawati \& Yulianti, 2010).

\section{Audit Committee}

The size of the audit committee has been discussed in various corporate governance guidelines, such as the Cadbury Report and the Smith Report where the report states that the number of audit committee members should not be less than three (Al-sayani et al., 2020). POJK No. 55/POJK.04/2015 stipulates that the audit committee consists of at least three members who come from independent commissioners and parties outside management (OJK, 2015). An audit committee consisting of three or more independent members is intended to test and assess the fairness of the financial statements (Silfi, 2016).

The expertise possessed by the audit committee regarding financial and accounting reports, both in the use of certain accounting methods and ways to avoid risks, allows the company to be monitored and controlled (Apriyanti \& Arifin, 2021). The audit committee is responsible for ensuring that the company complies with applicable laws and regulations, as well as ensuring effective control over conflicts of interest (Agustina \& Mulyani, 2019). 
Nida Ulya Sofana et al.

\section{Earnings Quality}

Earnings quality can be measured by the quality of income ratio, which is comparing operating cash flow with net income before tax (Taruno, 2013). JIAFR | 250 The higher the calculation ratio, the higher the quality of earnings (Hakim \& Abbas, 2019). Earnings quality ratio measured from operating activity cash flow is able to describe the company's ability in three ways, namely generating cash to meet company commitments (interest, taxes, and dividends), generating cash from operating profit and showing cash profit in the company's operating profit (Sirait, 2017).

Profits can experience a decline in quality when faced with agency conflicts. This conflict occurs because of the separation between ownership and management of the company, so that the principal (owner and shareholder) and agent (management) have opposing interests. Management tends to report earnings opportunistically to support their personal interests. In this situation, a corporate governance mechanism is needed as a controller to align the interests of all parties (Nadirsyah \& Muharram, 2016).

\section{Hypothesis Development}

Financial ratios that describe the relationship between debt and assets or capital are called leverage. The amount of leverage indicates that the company's debt level is high compared to its capital so that investors are reluctant to respond to earnings information that contains high leverage (Marsela \& Maryono, 2017). Companies with high debt ratios are more motivated to fulfill debt contractual agreements in various ways (Ali et al., 2007). The high leverage in a company is caused by the company's inability to finance its operational activities using capital, forcing the company to make loans. The company's performance will be more driven by the management to pay off the company's debts (Murniati et al., 2018). The company is considered unable to maintain a financial balance in the use of funds between available capital and required capital (Silfi, 2016). On the other hand, debt restrictions on companies make it difficult for managers to manipulate earnings (Chung et al., 2004). The existence of sharia stock selection based on 
debt ratios and non-halal income ratios has a positive relationship with earnings quality (Sugiarti \& Habibi, 2017).

$H_{1}$ : Debt to assets ratio has a negative effect on earnings quality

$\mathrm{H}_{2}$ : Debt to equity ratio has a negative effect on earnings quality

$H_{3}: \quad$ Non-halal income ratio has a negative effect on earnings quality

Agency theory shows that the behavior of managers who do not own shares in the company is likely to be influenced by benefits other than just the goal of maximizing company value (Fama et al., 1983). On the other hand, if the manager owns shares in the company, the manager gradually aligns his interests with other shareholders (Hashmi et al., 2018). The more shares owned by the manager, it can reduce the act of earnings manipulation by management (Jung \& Young, 2002). Instinctively, managers who also act as shareholders will avoid profit manipulation. This has an impact on increasing the company's performance to generate quality profits because the manager's position is the same as the shareholder (Maharani, 2015).

\section{$H_{4}$ : Managerial ownership has a positive effect on earnings quality}

Independent commissioners have a role in overseeing the company's performance to minimize agency conflicts between the board of directors or management and shareholders (Sugianto \& Sjarief, 2018). Companies with a more independent composition of the board of commissioners have a lower ability to commit fraud (Klein, 2000). Independent commissioners can make an effective contribution to the results of the process of preparing quality financial reports and avoid fraudulent financial statements (Budianto et al., 2018). The greater the proportion of independent commissioners has the potential to reduce earnings management so that the quality of earnings increases (Darabali \& Saitri, 2016).

\section{$H_{5}$ : Independent commissioners have a positive effect on earnings quality}

Based on agency theory, institutional investors can exercise control over company management. According to Bushee in Moradi and Nezami (2011), institutional investors are shareholders who come from outside the company, 
Nida Ulya Sofana et al.

such as institutions or other companies owned by non-bank financial institutions. Institutional investors are considered as professional investors with respect to the amount of investment and knowledge possessed in carrying out the supervisory function of management (Bartov et al., 2000) so that the existence of institutional ownership can reduce agency conflict (Puspitowati \& Mulya, 2014). In addition, institutional ownership can spur management to improve company performance and present financial reports well to improve earnings quality (Velury \& Jenkins, 2006).

\section{$H_{6}$ : Institutional ownership has a positive effect on earnings quality}

The audit committee was formed by the board of commissioners to carry out the internal control function related to the management of the company and to assist the duties of the board of commissioners, especially in dealing with issues related to the company's accounting policies and maintaining the credibility of financial reporting (Davidson et al., 2005). A larger number of audit committee members is more effective in monitoring financial statements (Bédard \& Gendron, 2010). The formation of the audit committee is expected to reduce earnings management activities which will have an impact on the decline in earnings quality (Darabali \& Saitri, 2016). This is in line with agency theory that a larger number of audit committee members allows a better supervisory function to improve the quality of financial reporting (Al-sayani et al., 2020).

\section{$H_{7}:$ The audit committee has a positive effect on earnings quality}

\section{Research Methods}

The population used in this study are all companies that are members of the Indonesian Sharia Stock Index (ISSI) in 2017-2019. Determination of the sample in this study used a non-probability sampling method with purposive sampling technique based on the following criteria: (1) companies registered with ISSI during 2017-2019, (2) companies that have consistently never been issued or have just entered the ISSI listing during 2017-2019, (3) companies that consistently submit annual reports during 2017-2019, (4) companies 
that provide financial reports in rupiah, (5) companies that consistently have positive profits in 2017-2019.

The data collection method chosen in this study is the documentation method which is carried out by searching for written objects, such as books, magazines, documents, regulations, meeting minutes, diaries, and others. (Arikunto, 2006). The documentation method in this study is the company's annual report issued by the company at ISSI in the 2017-2019 period and obtained through the website www.idx.co.id and literature study through books, scientific journals, and other written sources. The data were processed and analyzed using multiple linear regression model with SPSS 22 and obtained the following model:

$$
Y=+X 1+X 2+X 3+X 4+X 5+X 6+X 7+e
$$

\section{Table 1. Variable Measurement}

\begin{tabular}{|c|c|c|c|}
\hline & Variable & Abbreviation & Measurement \\
\hline \multicolumn{3}{|c|}{ Dependent } & $=\frac{\text { Operating Cash Flow }}{} \times 100 \%$ \\
\hline \multirow[t]{2}{*}{-} & \multirow{2}{*}{$\begin{array}{l}\text { Earnings Quality } \\
\text { (Y) }\end{array}$} & \multirow{2}{*}{ QI } & $=\overline{\text { Earning Before Interest tax }} \times 100 \%$ \\
\hline & & & $\begin{array}{l}\text { (Hakim \& Abbas, 2019), (Taruno, } \\
\text { 2013) }\end{array}$ \\
\hline \multicolumn{4}{|c|}{ Independent } \\
\hline \multirow[t]{2}{*}{1.} & Debt to Assets & DAR & $=\underline{\text { Total utang berbasis bunga }}$ \\
\hline & Ratio $(\mathrm{X} 1)$ & & $=\frac{\text { Total aset }}{\text { Toris }} \times 100 \%$ \\
\hline 2. & $\begin{array}{l}\text { Debt to Equity } \\
\text { Ratio (X2) }\end{array}$ & DER & $=\frac{\text { Total utang berbasis bunga }}{\text { Total modal }} \times 100 \%$ \\
\hline 3. & $\begin{array}{l}\text { Non-Halal } \\
\text { Income Ratio (X3) }\end{array}$ & RPNH & $=\frac{\text { Total pendapatan non halal }}{\text { Total pendapatan usaha dll }} \times 100 \%$ \\
\hline \multirow[t]{2}{*}{4.} & & & $\begin{array}{l}\text { (OJK, 2017), (DSN, 2003) } \\
\text { Jumlah saham manajemen }\end{array}$ \\
\hline & Ownership (X4) & KPM & 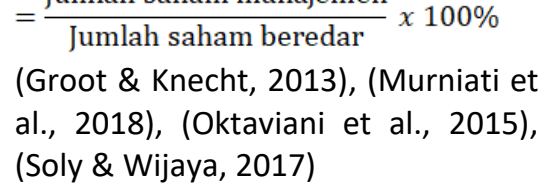 \\
\hline 5. & Independent & & \\
\hline
\end{tabular}


Nida Ulya Sofana et al.

Commissioner KI (X5)

6. Institutional

Ownership (X6)

$\mathrm{KPI}$

JIAFR | 254

7. Audit Committee

(X7)

KA $=\frac{\text { Jumlah komisaris independen }}{\text { Jumlah dewan komisaris }} \times 100 \%$

(Darabali \& Saitri, 2016), (Yushita et al., 2013)

$=\frac{\text { Jumlah saham institusi }}{\text { Jumlah saham beredar }} \times 100 \%$

(Puspitowati \& Mulya, 2014), (Budianto et al., 2018)

Value 1: audit committee consisting of more than three people

Score 0: audit committee with at least three members

(Silfi, 2016), (Al-sayani et al., 2020), (OJK, 2015)

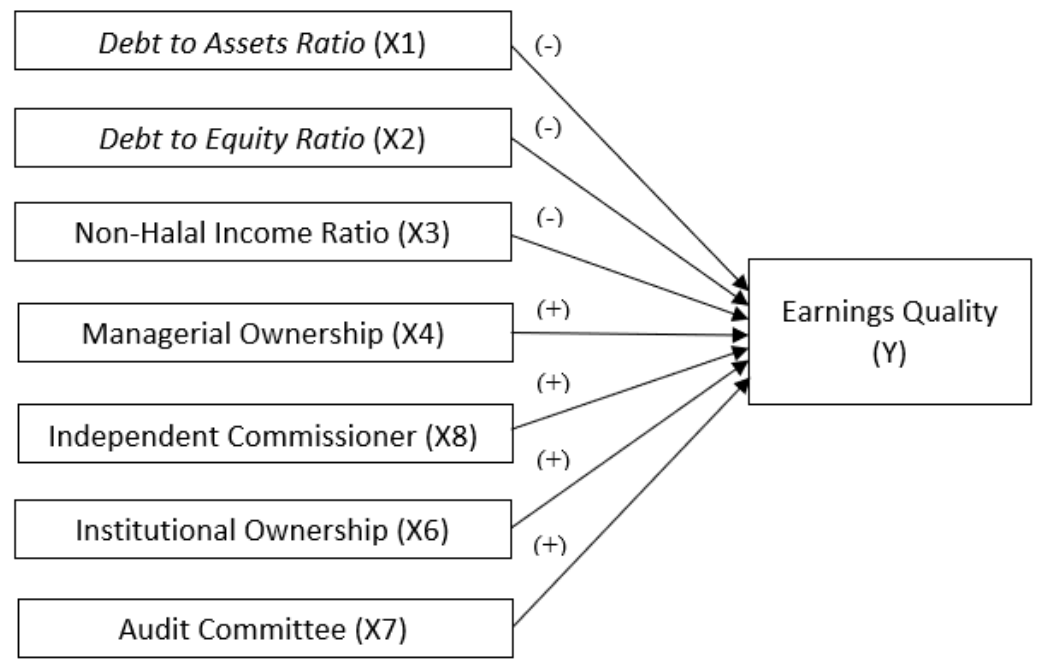

Figure 3. Research Framework 


\section{Results and Discussion}

Based on table 2, information is obtained that $\mathrm{N}$ (data volume) during 2017-2019 was 201 samples, while the missing was 0 . The average value of debt to assets ratio, debt to equity ratio, and non-halal income ratio were 18 respectively. 0,11,36,47 and 1.32. This means that these three ratios do not violate the POJK and the MUI DSN Fatwa. On the other hand, the average values of managerial ownership, independent commissioners, institutional ownership, and earnings quality are 2.95, 40.59, 76.36, and 61.33, respectively.

Table 3 shows that the data used in the study has a significance value of 0.200. That is, the research data are normally distributed because the significance value is more than 0.05 .

Table 4 shows that the regression model does not suffer from multicollinearity disorders. This can be seen in the tolerance value for no independent variable which has a tolerance value of less than 0.01 . Meanwhile, the value of Variance Inflation Factor (VIF) of all independent variables is more than 0.01 . So it can be concluded that there is no multicollinearity between independent variables in the regression model.

Table 2. Research Descriptive Statistics

Descriptive Statistics

\begin{tabular}{lrrrrr}
\hline & N & Minimum & Maximum & Mean & Std. Deviation \\
\hline DAR & 201 &, 89 & 47.81 & 18,1128 & 11.96553 \\
DER & 201 &, 42 & 177.51 & 36.4739 & 34.07705 \\
RPNH & 201 &, 01 & 9.31 & 1.3234 & 1.57529 \\
KPM & 201 &, 00 & 46.75 & 2.9583 & 8.10456 \\
KI & 201 & 22.22 & 75.00 & 40.5931 & 9.72150 \\
KPI & 201 &, 05 & 99.91 & 76.3616 & 24.77063 \\
KA & 201 &, 00 & 1.00 &, 0547 &, 22801 \\
QI & 201 & -163.30 & 198.84 & 61.3329 & 61.43116 \\
Valid N (listwise) & 201 & & & & \\
\hline
\end{tabular}

Source: Secondary Data Processed from SPSS 22, 2021 
Nida Ulya Sofana et al.

Table 3. Normality Test

One-Sample Kolmogorov-Smirnov Test

JIAFR $\mid 256$

\begin{tabular}{llr}
\hline & & Unstandardized Residual \\
\hline $\mathrm{N}$ & & 201 \\
Normal Parameters, b & mean &, 0000000 \\
& Std. Deviation & 58.57470044 \\
Most Extreme Differences & Absolute &, 033 \\
& Positive &, 032 \\
& negative &,- 033 \\
Test Statistics & &, 033 \\
asymp. Sig. (2-tailed) & & $, 200 \mathrm{c}, \mathrm{d}$ \\
\hline
\end{tabular}

a. Test distribution is Normal.

b. Calculated from data.

c. Lilliefors Significance Correction.

$d$. This is a lower bound of the true significance.

Source: Secondary Data Processed from SPSS 22, 2021

Table 4. Multicollinearity Test

Coefficients a

\begin{tabular}{lrrrrrrr}
\hline Model & \multicolumn{2}{c}{$\begin{array}{c}\text { Unstandardized } \\
\text { Coefficients } \\
\text { Std. }\end{array}$} & \multicolumn{2}{c}{$\begin{array}{c}\text { Standardized } \\
\text { Coefficients }\end{array}$} & & & \multicolumn{2}{c}{ Collinearity Statistics } \\
& \multicolumn{1}{c}{ B } & \multicolumn{1}{c}{ Error } & \multicolumn{1}{c}{ Beta } & \multicolumn{1}{c}{ t } & \multicolumn{1}{c}{ Sig. } & Tolerance & VIF \\
\hline (Constant) & 46,434 & 24,033 & & 1,932 & 0.055 & & \\
DAR &, 443 &, 811 &, 086 &, 546 & .585 &, 189 & 5,297 \\
DER &,- 524 &, 286 &,- 291 & $-1,834$ &, 068 &, 187 & 5,338 \\
RPNH & 5,935 & 2,733 &, 152 & 2,171 &, 031 &, 959 & 1.043 \\
KPM &, 673 &, 584 &, 089 & 1,153 &, 251 &, 794 & 1,259 \\
KI &,- 164 &, 444 & -026 &,- 369 &, 712 &, 956 & 1.046 \\
KPI &, 290 &, 191 &, 117 & 1.522 &, 130 &, 797 & 1.254 \\
KA & 11,860 & 18,641 & .044 &, 636 &, 525 &, 984 & 1.016 \\
\hline
\end{tabular}

a. Dependent Variable: QI

Source: Secondary Data Processed from SPSS 22, 2021

The results of the heteroscedasticity test in this study indicate that the regression model does not experience heteroscedasticity disorders. It can be seen from figure 4 that the scatterplot graph shows the distribution of the points without forming a certain pattern and spreads either above or below 0 . 


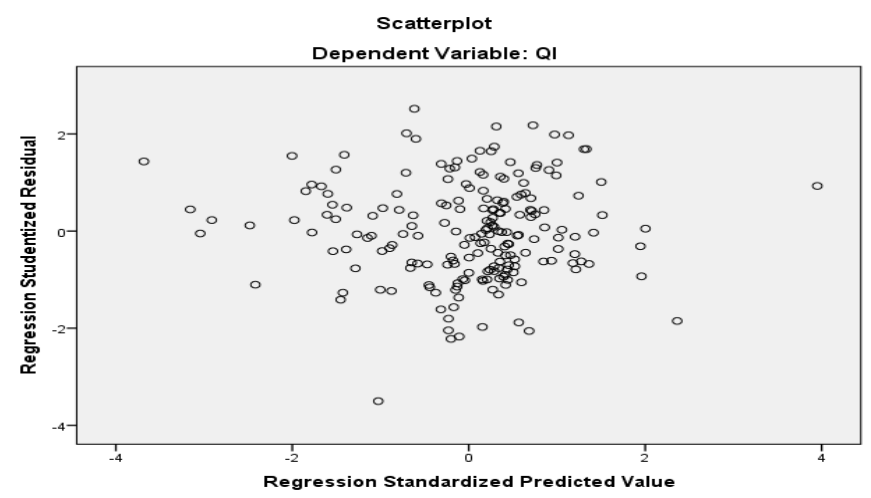

JIAFR | 257

Figure 4. Heteroscedasticity Test

Source: Secondary Data Processed from SPSS 22, 2021

Table 5. Autocorrelation Test

\begin{tabular}{lccccr}
\multicolumn{5}{c}{ Model Summary b } \\
\hline Model & $\mathbf{R}$ & R Square & $\begin{array}{c}\text { Adjusted R } \\
\text { Square }\end{array}$ & $\begin{array}{c}\text { Std. Error of } \\
\text { the Estimate }\end{array}$ & Durbin-Watson \\
\hline 1 &, $301 a$ &, 091 & 0.058 & 59,62748 & 1,981 \\
\hline a. Predictors: (Constant), KA, KPI, KI, RPNH, DAR, KPM, DER \\
b. Dependent Variable: QI \\
Source: Secondary Data Processed from SPSS 22, 2021
\end{tabular}

In Table 5 it can be seen that the statistical test obtained Durbin Watson's value of 1.988. Obtained values (dl of 1.698) and (du of 1.8415) for $n=201$ and $\mathrm{k}=7$. Durbin Watson's calculation results are in the area $\mathrm{du}<\mathrm{d}<4$-du $(1.8415<1.988<2.1585)$ then it can be concluded that the regression model in this study has no autocorrelation problem.

Based on Table 6, the regression equation is obtained as follows: (1) Constant $(\alpha)$ of 46,434 indicates that if there are no independent variables $(\mathrm{X} 1, \mathrm{X} 2, \mathrm{X} 3, \mathrm{X} 4, \mathrm{X} 5, \mathrm{X} 6, \mathrm{X} 7=0$ ), then earnings quality is $46.43 \%$, (2) If the amount of 1 (debt to assets ratio) $=0.443$, it indicates that if the debt to assets ratio is increased by 1 time, it will be followed by an increase in the value of earnings quality by $0.44 \%$ assuming other variables remain, (3) If the amount of 2 (debt to equity ratio) $=-0.524$, it indicates that every increase in debt to 
Nida Ulya Sofana et al.

equity ratio by 1 time will be followed by a decrease in the value of earnings quality by $0.52 \%$ assuming other variables remain, (4) If the amount 3 (nonhalal income ratio) $=5.935$, it shows that if the ratio of non-halal income is increased by 1 time, it will be followed by an increase in the value of earnings quality by 5,94\% assuming other variables remain. (5) If the amount of 4 (managerial ownership) $=0.673$, it indicates that if managerial ownership is increased by 1 time, it will be followed by an increase in the value of earnings quality by $0.67 \%$ assuming other variables are fixed, (6) If the amount of 5 (independent commissioner) $=-0.164$, it indicates that each increase in independent commissioners by 1 time, it will be followed by a decrease in earnings quality value of $0.16 \%$ assuming other variables remain, (7) If the amount 6 (institutional ownership) $=0.290$, it indicates that if institutional ownership is increased by 1 time, it will be followed by an increase in the value of earnings quality by $0.29 \%$ with the assumption that other variables remain, (8) If the number 7 (audit committee) $=11,860$, it indicates that if the audit committee is increased by 1 time, it will be followed by an increase in the value of earnings quality by $11,86 \%$ assuming other variables are fixed.

Table 6. Multiple Linear Regression Analysis

Coefficients a

\begin{tabular}{|c|c|c|c|c|c|c|}
\hline & & \multicolumn{2}{|c|}{$\begin{array}{l}\text { Unstandardized } \\
\text { Coefficients }\end{array}$} & \multirow{2}{*}{$\begin{array}{c}\text { Standardized } \\
\text { Coefficients } \\
\text { Beta } \\
\end{array}$} & \multirow[b]{2}{*}{$t$} & \multirow[b]{2}{*}{ Sig. } \\
\hline \multicolumn{2}{|c|}{ Model } & B & Std. Error & & & \\
\hline \multirow[t]{8}{*}{1} & (Constant) & 46,434 & 24,033 & & 1,932 & 0.055 \\
\hline & DAR & ,443 & ,811 & ,086 & ,546 & .585 \\
\hline & DER &,- 524 & ,286 &,- 291 & $-1,834$ & ,068 \\
\hline & RPNH & 5,935 & 2,733 & 152 & 2,171 & ,031 \\
\hline & KPM & ,673 &, 584 & 089 & 1,153 & ,251 \\
\hline & $\mathrm{KI}$ &,- 164 & ,444 &,- 026 &,- 369 & ,712 \\
\hline & KPI & ,290 & 191 & 117 & 1.522 & , 130 \\
\hline & KA & 11,860 & 18,641 & .044 & ,636 & ,525 \\
\hline
\end{tabular}

a. Dependent Variable: QI

Source: Secondary Data Processed from SPSS 22, 2021 
Table 7. Partial Test (t-test)

Coefficients a

\begin{tabular}{|c|c|c|c|c|c|c|}
\hline \multirow[b]{2}{*}{ Mod } & & \multicolumn{2}{|c|}{$\begin{array}{l}\text { Unstandardized } \\
\text { Coefficients }\end{array}$} & \multirow{2}{*}{$\begin{array}{l}\text { Standardized } \\
\text { Coefficients } \\
\text { Beta }\end{array}$} & \multirow[b]{2}{*}{$t$} & \multirow[b]{2}{*}{ Sig. } \\
\hline & & B & Std. Error & & & \\
\hline \multirow[t]{8}{*}{1} & (Constant) & 46,434 & 24,033 & & 1,932 & 0.055 \\
\hline & DAR & ,443 & ,811 & ,086 & ,546 & .585 \\
\hline & DER &,- 524 & ,286 &,- 291 & $-1,834$ & ,068 \\
\hline & RPNH & 5,935 & 2,733 & ,152 & 2,171 & ,031 \\
\hline & KPM & ,673 & ,584 & 089 & 1,153 & ,251 \\
\hline & $\mathrm{KI}$ &,- 164 & ,444 &,- 026 &,- 369 & ,712 \\
\hline & KPI & ,290 & 191 & 117 & 1.522 & 130 \\
\hline & KA & 11,860 & 18,641 & .044 & ,636 &, 525 \\
\hline
\end{tabular}

a. Dependent Variable: QI

Source: Secondary Data Processed from SPSS 22, 2021

Table 8. Simultaneous Test (F-Test)

ANOVA a

\begin{tabular}{llrrrrr}
\hline & Model & Sum of Squares & df & Mean Square & F & Sig. \\
\hline 1 & Regression & 68558,479 & 7 & 9794,068 & 2,755 &, $009 \mathrm{~b}$ \\
& Residual & 686199,106 & 193 & 3555,436 & & \\
& Total & 754757.586 & 200 & & & \\
\hline
\end{tabular}

a. Dependent Variable: QI

b. Predictors: (Constant), KA, KPI, KI, RPNH, DAR, KPM, DER

Source: Secondary Data Processed from SPSS 22, 2021

Based on Table 7, the following information is obtained: (1) The results of hypothesis testing (t-test) of the debt to assets ratio variable produce a tcount of 0.546 with a probability of 0.585 . The probability value is greater than $0.05(0.585>0.05)$ so that Ho is accepted and Ha is rejected. Thus, it can be concluded that the debt to assets ratio has a positive and insignificant effect on earnings quality. (2) The results of hypothesis testing (t-test) for the variable debt to equity ratio produce a $t$-value of -1.834 with a probability of 0.068 . The probability value is greater than $0.05(0.068>0.05)$ so that Ho is accepted and Ha is rejected. Thus, it can be concluded that the debt to equity ratio has a negative and insignificant effect on earnings quality. 
Nida Ulya Sofana et al.

(3) The results of the hypothesis test (t-test) for the non-halal income ratio variable produce a t-value of 2.171 with a probability of 0.031 . The probability value is less than $0.05(0.031<0.05)$ so that Ho is rejected and $\mathrm{Ha}$ JIAFR | 260 is accepted. Thus, it can be concluded that the ratio of non-halal income has a significant effect on earnings quality. (4) The results of the hypothesis test (ttest) for the managerial ownership variable resulted in a t-count of 1.153 with a probability of 0.251 . The probability value is greater than $0.05(0.251>$ 0.05 ) so that Ho is accepted and Ha is rejected. Thus, it can be concluded that managerial ownership does not have a significant positive effect on earnings quality. (5) The results of the hypothesis test (t-test) for the independent commissioner variable resulted in a t-count of -0.369 with a probability of 0.712 . The probability value is greater than $0.05(0.712>0.05)$ so that Ho is accepted and Ha is rejected. Thus, it can be concluded that independent commissioners have no negative and significant effect on earnings quality.

(6) The results of hypothesis testing (t-test) for institutional ownership variables produce a $t$-value of 1.522 with a probability of 0.130 . The probability value is greater than $0.05(0.130>0.05)$ so that Ho is accepted and Ha is rejected. Thus, it can be concluded that institutional ownership does not have a significant positive effect on earnings quality. (7) The results of the hypothesis test (t-test) for the audit committee variable resulted in a t-count of 0.636 with a probability of 0.525 . The probability value is greater than 0.05 $(0.525>0.05)$ so that Ho is accepted and Ha is rejected. Thus it can be concluded that the audit committee does not have a significant positive effect on earnings quality.

Based on Table 8, it is known that the F-count value is 2.755 and the Ftable value is 2.055363. The value of F-count is greater than F-table (2.755 > 2.055363). So, it can be concluded that the debt to assets ratio, debt to equity ratio, non-halal income ratio, managerial ownership, independent commissioners, institutional ownership, and the audit committee jointly affect earnings quality. 
The effect of sharia share selection based on financial ratio and ...

\section{The Effect of Debt to Assets Ratio (DAR) on Earnings Quality}

The t-count value of the debt to assets ratio (X1) is 0.546 with a significant value of $0.585>0.05$ so that the debt to assets ratio variable does not have a significant positive effect on earnings quality. That is, Hypothesis 1 is rejected. The debt to assets ratio does not have a positive and significant effect on the earnings quality of companies incorporated in the Indonesia Sharia Stock Index in 2017-2019. Debt to assets ratio in this study 18.11\%. This amount has no significant effect and shows that the ratio of debt to company assets which represents the capital structure does not affect the market reaction. Investors do not pay much attention to the debt ratio in their investment decisions. In their investment decisions, investors tend to consider other fundamental aspects, such as profit, so that the company is free to add assets or capital through debt to increase profits. The results of this study are in accordance with research conducted by Wati and Putra (2017), Darabai and Saitri (2016), and Marsela and Maryono (2017). The relationship with agency theory is that companies with high debt to assets ratios are motivated to efficiently manage debt. However, contrary to the results of research by Warianto and Rusiti (2016) that higher debt motivates management to carry out earnings management in order to avoid debt contract violations.

\section{The Effect of Debt to Equity Ratio (DER) on Earnings Quality}

The t-count value of the debt to equity ratio $(\mathrm{X} 2)$ is -1.834 with a significant value of $0.068>0.05$ so that the debt to equity ratio variable has a negative but not significant effect on earnings quality. That is, Hypothesis 2 is rejected. Debt to equity ratio has a negative and insignificant effect on the earnings quality of companies incorporated in the Indonesia Sharia Stock Index in 2017-2019. The average debt to quity ratio in this study is $36.47 \%$. This study shows that the source of funds used by the company in its operations does not affect the increase in profit and operating cash flow which is calculated as a component of earnings quality. On the other hand, an increase in the company's debt will spur management to improve its performance so that the company is able to pay its debts. As a result, the 
Nida Ulya Sofana et al.

company is able to develop and improve the quality of its earnings without having to add debt. The results of this study are similar to those conducted by Hakim and Abbas (2019), Primary and Sunarto (2018), Tanjung (2019), Murniati, Literature, and Rupa (2018), Nugrahani (2019) and Anjelica and Albertus (2014). If it is associated with agency theory, it shows that management has the opportunity to maximize contractual benefits.

\section{The Effect of Non-Halal Income Ratio on Earning Quality}

The t-count value of the non-halal income ratio (X3) is 2.172 with a significant value of $0.031<0.05$ so that the non-halal interest income ratio variable has a significant effect on earnings quality. That is, Hypothesis 3 is accepted. The ratio of non-halal income has a negative and significant effect on the quality of earnings of companies incorporated in the Indonesian Sharia Stock Index in 2017-2019. This study supports Hypothesis 3 which shows that the relationship between the ratio of non-halal income in the form of interest income and earnings quality is related to persistence or stability. These results are in line with research by Sugiarti and Habibi (2017) that interest income affects the inconsistency of operating cash flows due to the effect of fluctuations in interest rates. While operating cash flow is considered as a component of calculating earnings quality.

\section{The Effect of Managerial Ownership on Earnings Quality}

The t-count of managerial ownership (X4) is 1.153 with a significant value of $0.251>0.05$ so that the ownership variable does not have a significant positive effect on earnings quality. That is, Hypothesis 4 is rejected. Managerial ownership does not have a significant positive effect on the earnings quality of companies incorporated in the 2017-2019 Indonesian Sharia Stock Index. The average managerial ownership in this study is only $2.9 \%$. Even the smallest percentage of managerial ownership is $0.00 \%$ while the largest percentage is only $46.75 \%$. The percentage which is small and does not dominate is deemed insufficient to contribute to the quality of the company's earnings. In addition, the share ownership of companies in 
Indonesia tends to be concentrated in one group so that the distribution is not evenly distributed. Companies whose share ownership is more spread out minimize the opportunity for management to manipulate earnings so that the smaller the share ownership by management, the quality of earnings will increase. These results are in accordance with the research of Pratama and Sunarto (2018), Sugianto and Sjarief (2018), Budianto et al. (2018), Soly and Novia (2017), Oktaviani et al. (2015) and Yushita et al. (2013). In contrary, the research of Darabali and Saitri (2016) which shows the existence of share ownership by the management, the position of management and shareholders have the same interest in improving the company's performance to generate quality profits.

\section{The Influence of Independent Commissioners on Earnings Quality}

The independent commissioner's t-count value is -0.369 with a significant value of $0.712>0.05$ so that the independent commissioner variable does not have a significant negative effect on earnings quality. That is, Hypothesis 5 is rejected. Independent commissioners do not have a significant negative influence on the earnings quality of companies incorporated in the 20172019 Indonesian Sharia Stock Index. Independent commissioners can improve earnings quality by limiting the level of earnings management and optimizing the supervisory function of reporting financial statements but it is not significant. The insignificant effect caused by the presence of independent commissioners may only be intended to comply with Good Corporate Governance regulations. This can be seen in the average independent commissioners in this study amounted to $40.59 \%$. Other than that, the minimum requirement of $30 \%$ independent commissioners is considered to have not been able to dominate the policies taken by the board of commissioners while the dominance of independent commissioners can carry out the supervisory function more effectively. The results of this study are in line with research conducted by Sugianto and Sjarief (2018), Farida and Kusumaningtyas (2017), Marlinah (2020), Muid (2009), Murniati et al. (2018) and Novieyanti and Kurnia (2016). However, this study contradicts 
Nida Ulya Sofana et al.

the results of Meidayanthi and Saitri's research (2016) that the board of commissioners plays an important role in ensuring the implementation of corporate strategy and supervising management.

\section{The Effect of Institutional Ownership on Earnings Quality}

The t-count value of institutional ownership is 1.522 with a significant value of $0.130>0.05$ so that the variable of institutional ownership does not have a significant positive effect on earnings quality. That is, Hypothesis 6 is rejected. Institutional ownership does not have a significant positive effect on the quality of companies incorporated in the Sharia Stock Index in 20172019. Institutional ownership does not have a significant effect on earnings quality because the existence of institutional parties who own company shares does not have the power to influence the components presented in the financial statements by management. In addition, although the average institutional ownership in this study is $76.36 \%$, it is still not able to optimize supervision of management performance. This indicates that institutional investors are not able to improve earnings quality. The results of this study are similar to those of Yushita et al. (2013), Pratama and Sunarto (2018), Murniati et al. (2018) and Polimpung (2020). However, this research is not in line with the research of Indrawati and Yulianti (2010) that high institutional ownership can reduce earnings manipulation initiatives by management which ultimately can improve the quality of reported earnings.

\section{The Influence of the Audit Committee on Earnings Quality}

The t-count value is 0.636 with a significant value of $0.525>0.05$ so that the audit committee variable does not have a significant positive effect on earnings quality. That is, Hypothesis 7 is rejected. The audit committee does not have a significant positive influence on the earnings quality of companies incorporated in the 2017-2019 Indonesian Sharia Stock Index. The audit committee has not been able to significantly influence earnings because the formation of an audit committee by an independent commissioner is only to fulfill the requirements of the regulator. This is evident from the number of 
members of the audit committee that is not varied. Most companies form an audit committee with 3 members to meet the minimum requirements from the Financial Services Authority. Besides that, the company has not been able to optimize the performance of the audit committee because the formation of the audit committee is still not fully independent by the board of commissioners. The results of this study are in accordance with research conducted by Al-sayani et al. (2020), Indrawati and Yulianti (2010), Puspitowati and Mulya (2014), Yushita et al. (2013), and Muid (2009). This study contradicts the research of Darabali and Saitri (2016) stating that the audit committee as an independent party that has the function of monitoring the financial reporting process will reduce interference in information.

\section{Conclusion}

Based on the research conducted, the conclusion is that there is one indicator of Islamic stock selection based on financial ratios that has a significant effect on the quality of company earnings, namely the non-halal income ratio while the other two indicators (debt to assets ratio and debt to equity ratio) do not have a significant effect on earnings quality. In addition, the corporate governance mechanism is proven to have no significant effect on the quality of corporate earnings. Companies that are members of the Indonesian Sharia Stock Index are expected to be able to improve the quality of the presentation of financial statements and the implementation of good corporate governance so that the profit presented has a better quality. On the other hand, investors are expected to study the company's annual report as a consideration for investment decisions. Further researchers are expected to extend the research period and expand the research model. This study has limitations because there are no direct visits to the company so that the data obtained are limited.

\section{References}

Agustina, C., \& Mulyani, SD (2019). The Effect of Remuneration of the Board of Directors, Leverage and Effectiveness of the Audit Committee on Earnings Quality with Company Size as Moderating Variable. Trisakti 
Nida Ulya Sofana et al.

Journal of Accounting, 4(2), 227-244. https://doi.org/10.25105/jat.v4i2.5245

Al-sayani, YM, Naimi, M., Nor, M., Afza, N., Al-sayani, YM, Naimi, M., Nor, M., \& Amran, NA (2020). The influence of audit committee characteristics on JIAFR | 266 impression management in chairman statement: Evidence from Malaysia The influence of audit committee characteristics on impression management in chairman statement: Evidence from Malaysia. Cogent Business \& Management, 7(00). https://doi.org/10.1080/23311975.2020.1774250

Ali, A., Chen, T., \& Radhakrishnan, S. (2007). Corporate disclosures by family firms. Journal of Accounting and Economics, 44, 238-286. https://doi.org/10.1016/j.jacceco.2007.01.006

Anjelica, K., \& Prasetyawan, AF (2014). The Effect of Profitability, Company Age, Company Size, Audit Quality, and Capital Structure on Earning Quality. 6(1), 27-42. https://doi.org/https://doi.org/10.31937/akuntansi.v6i1.145

Apriyanti, HW, \& Arifin, M. (2021). Tax aggressiveness determinants. Journal of Islamic Accounting and Finance Research, 3(1), 27-52. https://doi.org/10.21580/jiafr.2021.3.1.7412

Arikunto. (2006). Research Procedure: A Practical Approach Revised V. LP3ES Edition.

Asogwa, CI, Ofoegbu, GN, Nnam, JI, \& Chukwunwike, OD (2019). Effect of corporate governance board leadership models and attributes on earnings quality of quoted nigerian companies. Cogent Business and Management, $6(1)$. https://doi.org/10.1080/23311975.2019.1683124

Bartov, E., Radhakrishnan, S., \& Krinsky, I. (2000). Investor sophistication and patterns in stock returns after earnings announcements. Accounting Review, 75(1), 43-63. https://doi.org/10.2308/accr.2000.75.1.43

Bédard, J., \& Gendron, Y. (2010). Strengthening the Financial Reporting System : Can Audit Committees Deliver ? 210, 174-210. https://doi.org/10.1111/j.1099-1123.2009.00413.x

Buchdadi, AD, Arafat, MY, \& Utaminingtyas, TH (2012). The Comparison of Value at Risk on Sharia Based Stock and Non-Sharia Based Stock: Case Study on Indonesia Capital Market During 2005-2008. SSRN Electronic Journal.https://doi.org/10.2139/ssrn.1711714 
Budianto, R., Samrotun, YC, \& Suhendro. (2018). The Effect of Good Corporate Governance (GCG) on Earnings Quality in Manufacturing Companies Listed on the IDX 2015-2017. National Seminar And Call Paper: Management, Accounting And Banking, 411-424.

Chung, R., Ho, S., \& Kim, J. (2004). Ownership structure and the pricing of discretionary accruals in Japan. Journal of International Accounting, Auditing \& Taxation, 13, 1-20. https://doi.org/10.1016/j.intaccaudtax.2004.02.003

Darabali, PM, \& Saitri, PW (2016). Analysis of Factors Affecting Earnings Quality in Manufacturing Companies on the Indonesia Stock Exchange 2010-2013. Journal of Accounting Research, 6(1), 46-60.

Davidson, R., Goodwin-stewart, J., \& Kent, P. (2005). Internal Governance Structures and Earnings Management. 45(August 2003), 241-267. https://doi.org/10.1111/j.1467-629x.2004.00132.x

Fama, EF, Jensen, MC, Journal, S., \& A, PP (1983). Separation of Ownership and Control Separation of Ownership And Control*. 26(2), 301-325. https://doi.org/https://doi.org/10.1086/467037

Farida, DN, \& Kusumaningtyas, M. (2017). The Influence of Independent Board of Commissioners and Managerial Ownership on Earnings Quality. Journal of STIE Semarang, 9(1), 50-71.

Fielnanda, R. (2017). Sharia Stock Screening Concept in Indonesia. AL-FALAH : Journal of Islamic Economics, 2(2). https://doi.org/10.29240/jie.v2i2.255

Fitri, H., Elmanizar, Nugraha, AT, Yakub, A., \& Cahyono, BP (2019). The application of agency theory in supply chain finance: A case of Indonesian manufacturing firms. International Journal of Supply Chain Management, 8(3), 23-32.

Groot, EA De, \& Knecht, EADK (2013). Managerial Ownership and Earnings Management in Times of Financial Crisis: Evidence from the USA Efstathios Spinos ( 366962 ). 366962.

Hakim, M., \& Abbas, D. (2019). The Influence of Company Size, Capital Structure, Liquidity, Investment Opportunity Set (Ios), and Profitability on Earning Quality (Food and Beverage Companies Listed on the Indonesia Stock Exchange 2013-2017). Competitive Journal of Accounting and Finance, 3(2), 26-51. https://doi.org/http://dx.doi.org/10.31000/c.v3i2 
Nida Ulya Sofana et al.

Hakim, S., \& Rashidian, M. (2004). How Costly is Investors' Compliance to Sharia ? 11th Economic Research Forum Annual Conference. Sharjah, UAE., 1-19. http://ejournal.narotama.ac.id/files/How Costly is Investors' Compliance with Sharia.pdf

JIAFR | 268 Hashmi, MA, Brahmin, RK, Lau, E., \& Hashmi, MA (2018). Political connections, family firms and earnings quality. https://doi.org/10.1108/MRR-05-2017-0136

Indrawati, N., \& Yulianti, L. (2010). Mechanism of Corporate Governance and Earnings Quality. Pekbis Journal, 2(2), 283-291.

Jung, K., \& Young, S. (2002). Ownership Structure and Earnings Informativeness Evidence from Korea. The International Journal of Accounting, 37, 301-325.

Finance, OJ (2017). POJK Number 35/POJK.04/2017. Financial Fervices Authority. $\quad$ https://www.ojk.go.id/id/kanal/pasarmodal/regulation/peraturan-ojk/Pages/Peraturan-Otoritas-JasaKeuangan-Nomor-35-POJK.04-2017-.aspx

Klein, A. (2000). Audit committee, board of director characteristics, and earnings management. 06.

Luayyi, S. (2012). Agency Theory and Earnings Management from the Ethical Viewpoint of Managers. El Muhasaba: Journal of Accounting, 1(2), 199216. https://doi.org/10.18860/em.v1i2.1871

Maharani, MP (2015). The Influence of Managerial Ownership, Institutional Ownership, Independent Board of Commissioners, Profit Organizations, and Leverage on Earnings Quality (Case Study on Manufacturing Companies Listed on the Stock Exchange 2010-2013). In Thesis UNNES. Semarang State University.

Marsela, SY, \& Maryono. (2017). The Influence of Good Corporate Governance, Leverage, Profitability and Company Size on Earning Quality (Case Study on Public Companies Included in the 2013-2016 CGPI Ratings). Dynamics of Accounting, Finance and Banking, 6(1), 4052.

Moradi, MA, \& Nezami, A. (2011). Influence of Ownership Structure on Earning Quality in the Listed Firms of Tehran Stock Exchange. International Journal of Business Administration, 2(4), 146-154. https://doi.org/10.5430/ijba.v2n4p146 
Muchtar, EH (2019). Shariah Stock Screening Process: Perspectives on Sharia Economics and Practitioners. Ad Deenar: Journal of Islamic Economics and Business, 3(2), 177-186. https://doi.org/10.30868/ad.v3i2.534

Muid, D. (2009). Effect of Corporate Governance Mechanism on Earnings Quality. Economic Focus, 4(2), 94-108. https://doi.org/https://doi.org/10.34152/fe.4.2.\%25p

Murniati, T., Sastri, IIDA. M., \& Rupa, IW (2018). Factors Affecting Earnings Quality in Manufacturing Companies Listed on the Indonesia Stock Exchange in 2012 - 2016. KRISNA Journal: Accounting Research Collection, 10(1), 89-101. https://doi.org/https://doi.org/10.22225/kr.10.1.707.89-101

Nadirsyah, N., \& Muharram, FN (2016). Capital Structure, Good Corporate Governance and Earnings Quality. Journal of Accounting and Business Dynamics, 2(2), 184-198. https://doi.org/10.24815/jdab.v2i2.4217

Nguyen, HA, Le, QL, Kim, T., Vu, A., Nguyen, HA, Le, QL, Kim, T., \& Vu, A. (2021). Cogent Business \& Management Ownership Structure and Earnings Management: Empirical Evidence from Vietnam. Cogent Business \& Management, https://doi.org/10.1080/23311975.2021.1980006

$8(1)$.

Novieyanti, IA, \& Kurnia. (2016). The Effect of Good Corporate Governance Mechanisms on Earning Quality in Manufacturing Companies. Journal of Accounting Science and Research, 5(11), 1-15.

Nugrahani, NI (2019). Effect of Financial Performance, Profit Growth, and Free Cash Flow on Earning Quality Endang Dwi Retnani Indonesian College of Economics (STIESIA) Surabaya. Journal of Accounting Science and Research, 8(11).

OJK, OJK (2015). POJK Number 55/POJK.04/2015.

Oktaviani, RN, Nur, E., \& Ratnawati, V. (2015). The Effect of Good Corporate Governance on Earnings Quality With Earnings Management as an Intervening Variable. Highlight, 10(1), 36-53. https://doi.org/10.31258/sorot.10.1.3203

Polimpung, LJC (2020). The Effect of Good Corporate Governance on the Quality of Company Earnings (Study on Consumer Goods Sector Companies in the Indonesia Stock Exchange 2016-2018 Period). Journal of Accounting, 12(2), 215-222. https://doi.org/10.28932/jam.v12i2.2305 
Nida Ulya Sofana et al.

Prasetyantoko. (2008). Corporate Governance Institutional Approach. PT Gramedia Pustaka Utama.

Pratama, AD, \& Sunarto. (2018). Capital Structure, Independent Commissioner, Managerial Ownership, Institutional Ownership and

JIAFR | 270 Company Size on Earnings Quality. Journal of Dynamics of Accounting, Finance and Banking, 7(2), 96-104.

Puspitowati, NI, \& Mulya, AA (2014). The Effect of Audit Committee Size, Board of Commissioners Size, Managerial Ownership, and Institutional Ownership on Earnings Quality (Empirical Study on Financial Sector Companies Listed on the Indonesia Stock Exchange Period 20082012). Journal of Accounting and Finance, 3(1), 219-239.

Ramdani, LA, \& Aziz, AA (2018). Comparison of the Business Screening Model and Financial Screening of the Global Sharia Stock Index. Iqtishaduna: Journal of Islamic Economics \& Finance, 9(1). https://doi.org/https://doi.org/10.20414/iqtishaduna.v9i1.684

Rivandi, M. (2018). The effect of intellectual capital disclosure, financial performance, and managerial ownership on firm value. Journal of Pundi, 02(01), 41-54. https://doi.org/https://doi.org/10.31575/jp.v2i1.61

Silfi, A. (2016). The Effect of Profit Growth, Capital Structure, Liquidity and Audit Committee on Earning Quality. Journal of Currency, 2(1), 17-26.

Sirait, P. (2017). Financial Statement Analysis. Yogyakarta: Equilibria.

Soly, N., \& Wijaya, N. (2017). Factors that affect earnings quality in manufacturing companies. Journal of Business and Accounting, 19(1), 47-55. https://doi.org/10.34208/jba.v19i1.64

Sugianto, S., \& Sjarief, J. (2018). Analysis of the Effect of Managerial Ownership, Proportion of Independent Commissioners, and Accounting Conservatism on Earnings Quality and Its Effect on Firm Value. Journal of Economia, 12(1), 80-102. https://doi.org/https://doi.org/10.25170/jara.v12i1.59

Sugiarti, L., \& Habibi, A. (2017). Islamic stock financial ratios, earnings quality and firm value.

Tanjung, PRS (2019). The Influence, Debt to Equity Ratio, Liquidity And Investment Opportunity Set (Ios) On Earnings Quality. Journal of Economics and the Public, 2(2), 119-130. 
Taruno, SA (2013). The Effect of Corporate Governance on Earnings Quality: Earnings Management as an Intervening Variable. 2(3), 323-329. https://doi.org/https://doi.org/10.15294/aaj.v2i3.22531

Velury, U., \& Jenkins, DS (2006). Institutional ownership and the quality of earnings. Journal of Business Research, 59(9), 1043-1051. https://doi.org/10.1016/j.jbusres.2006.05.001

Warianto, P., \& Rusiti, C. (2016). The Effect of Firm Size, Capital Structure, Liquidity and Investment Opportunity Set (Ios) on Earnings Quality in Manufacturing Companies Listed on The Stock Exchange. Mode, 26(1), 19. https://doi.org/10.24002/modus.v26i1.575

Wati, GP, \& Putra, IW (2017). The Effect of Firm Size, Leverage, And Good Corporate Governance on Earnings Quality. E-Journal of Accounting, 19(1), 137-167.

Yushita, AN, Rahmawati, \& Hanung Triatmoko. (2013). The Influence of Corporate Governance Mechanisms, Quality of External Auditors, and Liquidity on Earnings Quality. Journal of Economia, 9(2), 141-155. https://doi.org/https://doi.org/10.21831/economia.v9i2.1805

Yuwana, RW (2018). Legal Analysis of Sharia Stock Investment on Issuers Issued from the Indonesian Sharia Stock Index (ISSI) in the Az-Zari'ah Review. In Thesis UIN Sunan Kalijaga. UIN Sunan Kalijaga.

Zulkifli, \& Sulastiningsih. (1998). Conceptual Framework and Financial Reporting in an Islamic Perspective Islamic Accounting: State of the Art in the concept of Islam, it is believed that Islam is a religion. 2(2). 
JIAFR | 272 